Check for updates

New York

Cite this as: BMJ 2021;373:n1115 http://dx.doi.org/10.1136/bmj.n1115 Published: 29 April 2021

\title{
Covid-19: US relaxes rules on mask wearing for fully vaccinated people
}

\section{Janice Hopkins Tanne}

Americans who have been fully vaccinated can relax their use of face coverings, especially outdoors, under new rules from the US Centers for Disease Control and Prevention (CDC) announced by President Joe Biden on 27 April. ${ }^{1}$

Biden said that progress against covid-19 would lead to more normal life. He set a target for people to be able to get together with friends and family on 4 July, American Independence Day, which is traditionally a time for barbecues and family gatherings. ${ }^{2}$

In less than 100 days since he took office, said Biden, "Two thirds of our seniors are now fully vaccinated, and more than $80 \%$... have had at least one shot. That effort has resulted in a drop of $80 \%$ in deaths among American seniors, [and] a 70\% drop in hospitalisations.”

More than half of all Americans have received at least one shot of the vaccine. The CDC reported in a tweet that the current seven day average of new daily cases was 53 934, a 16\% decrease from the previous week. ${ }^{3}$

The agency explained that people are "fully vaccinated" if they have received two doses of the Pfizer-BioNTech or Moderna vaccine or one dose of the Johnson \& Johnson vaccine and are two weeks past the last dose.

It added that fully vaccinated people need not wear a mask when they walk, run, or cycle outdoors with members of their household, attend small outdoor gatherings with fully vaccinated family and friends, or dine at an outdoor restaurant with friends from multiple households. However, they should still wear a mask if attending a crowded outdoor event such as a live performance, parade, or sports event.

\section{"Simpler rules" needed}

Fully vaccinated people should continue to wear a mask for all indoor events, the CDC advised, such as visiting a barbershop or a hair salon; going to an uncrowded indoor shopping centre or museum; riding public transport; attending a small indoor gathering of fully vaccinated and unvaccinated people from multiple households; going to an indoor cinema; attending a full capacity worship service; singing in an indoor chorus; eating at an indoor restaurant or bar; and participating in high intensity indoor exercise.

Unvaccinated people, the CDC said, should wear masks except for outdoor exercise with members of their household or small outdoor gatherings with fully vaccinated family and friends.

Scott Gottlieb, former commissioner of the US Food and Drug Administration, applauded the CDC's new guidelines but called them late and confusing. "It's not very clear in terms of what they're prescribing," he said. "I think we need simpler rules if we're going to be prescribing something over society.

"I think the public health goal should be to try to protect vulnerable populations in congregate settings, so continue to focus on nursing homes, day care settings where small children are, and try to prevent large outbreaks, try to prevent superspreading events.”

Correction: We amended this story on 30 April 2021 because it referred to Scott Gottlieb as a former commissioner of the CDC rather than the FDA.

1 Centers for Disease Control and Prevention. When you've been fully vaccinated. 27 Apr 2021. https://www.cdc.gov/coronavirus/2019. ncov/vaccines/fully-vaccinated.html.

2 White House. Remarks by President Biden on the covid-19 response. 27 Apr 2021. https://www. whitehouse.gov/briefing-room/speeches-remarks/2021/04/27/remarks-by-president-biden-on-the-covid-19-response/.

3 Centers for Disease Control and Prevention. Twitter. 28 Apr 2021. https://twitter.com/CDCgov?ref_src=twsrc\%5Egoogle\%7Ctwcamp\%5Eserp\%7Ctwgr\%5Eauthor

4 Stankiewicz K. Dr Scott Gottlieb: New CDC mask guidance late and confusing, but a "step in the right direction." CNBC.com 2021 Apr 28. https://www.cnbc.com/2021/04/28/new-cdc-mask-guidance-is-confusingbut-the-right-step-scott-gottlieb.html.

This article is made freely available for use in accordance with BMJ's website terms and conditions for the duration of the covid-19 pandemic or until otherwise determined by BMJ. You may use, download and print the article for any lawful, non-commercial purpose (including text and data mining) provided that all copyright notices and trade marks are retained. 